\title{
Emerging Trends of Sez In India
}

\author{
S.Chandrachud ${ }^{1}$, Vels University \\ Dr. Gajalakshmi ${ }^{2}$, S.D.N.B.V. College
}

Key words: SEZ, FDI, Employment, Export and EPZ

\section{Introduction}

SEZ refers to Special Economic Zone, literally mean geographically demarcated region that has economic laws that are more liberal than the country's typical economic laws and where all the units therein have specific privileges. SEZs are specifically delineated duty-free enclaves and are deemed to be foreign territory for the purposes of trade operations, duties and tariffs. 1

\section{SEZ in Global scenario}

In 1896, the first industrial Park was set up in Manchester, called Free Trade Zone, designed to promote the free trade, conceptually improved by Hong Kong during the Post-Second world War, created economic quake elsewhere thereafter. In 1929, the first Special Economic Zone which was called as Special Zone, was introduced in Spain with the intention of improving the exports by value addition to the raw materials available in that country, conceptually improved by Deng Xiaoping, revolutionary veteran of China, for the past three decades, gave a economic quake to the concept of SEZ from1979. He used the SEZ as the economic quake to attain the success of his liberalized economic policies. Later the other developing countries, like UAE, Jordan, Philippines, Malaysia, Russia, Kazakhstan and south Korea are also chosen the Chinese path in their economies in terms of economic liberalization. Even most of the countries in south Asia - Nepal, Bangladesh, Sri Lanka and Pakistan have tried to promote their export.

\section{SEZ in Indian scenario}

The policy of SEZ was introduced in India on April 1, 2000 with a view to provide a more competitive free trade environment for exports. During the period from November 1, 2000 to February 10, 2006, the SEZs in India operated under the provisions of the Foreign Trade Policy. The principal goal is to increase foreign investment. Through the introduction of SEZs, India also wants to enhance its somewhat dismal infrastructural requirements, which, once they have been improved, will invite even more Foreign Direct Investment (FDI). Or put in the government's own words, the main objectives of the SEZs are:

(a) Generation of additional economic activity;

(b) Promotion of exports of goods and services;

(c) Promotion of investment from domestic and foreign sources;

(d) Creation of employment opportunities;

(e) Development of infrastructure facilities. 2

In fact, India was the first Asian country to recognize the importance and effectiveness of Export Processing Zone (EPZ) and the first EPZ came into being in 1965 in Kandla, Gujarat. But, since then there has not been done much to the strengthening of EPZs in India. In 2000, therefore, the government replaced the earlier regime of EPZ by a new scheme of SEZs, which encompassed a number of potential benefits that were missing in the earlier scheme. In May 2005, the SEZ Act 2 was passed by the Parliament and SEZ Rules 3 came into force from February 10, 2006, which not only simplified procedures but also extended single window clearance for matters relating to Central as well as state governments. The SEZ Rules provide for different minimum land requirement for different class of SEZs. The promotion of SEZs is expected to tackle wide range of structural bottlenecks created by monetary, fiscal, taxation, trade, tariff and labour policies, aside from overcoming complex procedures and infrastructure deficiencies (Aggarwal, 2006). It has been argued that since development of infrastructure requires huge capital investment and as implementation of structural reforms is time-consuming process, the establishment of SEZs would be the only realistic strategy governing the process of industrialization. Although SEZs offer numerous benefits, there are also various positive as well as negative features associated with the establishment of SEZs in India. It is, therefore, essential to analyze not only the 
potential benefits of SEZs but also the likely impact of establishment of SEZs on agricultural production, employment, water and food security.

This paper is an attempt to expose the emerging trends of SEZs through the comparative study of State wise SEZ approvals and Sector wise SEZ approvals. It also throws light on current status of SEZ in terms of employment generation, Capital investment and performance in exports.

\section{Features of SEZs}

The SEZs in India are not only expected to bring large flow of foreign direct investment but also domestic investment, which will help in generating additional economic activity in the form of creating employment opportunities, infrastructure development and enhancing productive capacity as well as capabilities. The salient features of the SEZ Act mainly revolve around

(i) satisfying the needs of all major stakeholders in an SEZ, including developers, operators, suppliers, residents, etc.,

(ii) making provisions of single window clearance mechanism

(iii) Providing attractive fiscal incentive package,

(iv) Establishing free trade and warehousing zones with a view to develop internationally competitive infrastructure facilities to augment import and export of commodities

(v) setting up of off shore banking units, and

(vi) Facilitating public private participation towards development of infrastructure.

The SEZ Rules provide for different minimum land requirement for different class of SEZs. Every SEZ is divided into a processing area where alone the SEZ units would come up and the non-processing area where the supporting infrastructure is to be created. The main purpose of framing SEZ rules to provide:

- " Simplified procedures for development, operation, and maintenance of the Special Economic Zones and for setting up units and conducting business in SEZs;

- Single window clearance for setting up of an SEZ;

- Single window clearance for setting up a unit in a Special Economic Zone;

- Single Window clearance on matters relating to Central as well as State Governments;

- Simplified compliance procedures and documentation with an emphasis on self certification

In order to attract investments into the SEZs in India, number of incentives and facilities have been offered to the SEZs are duty free import and domestic procurement of goods for development, operation and maintenance of SEZ units, 100\% Income tax exemption on export income for SEZ units under section 10AA of the Income Tax Act for first 5 years thereafter $50 \%$ of the ploughed back export profit for next 5 years, exemption from minimum alternate tax under section 115JB of the Income Tax Act, External Commercial borrowing by SEZ units up to US $\$ .500$ million in a year without any maturity restrictions through recognized banking channels, exemption from Central Sales Tax, single window clearance for Central and state level approvals and exemption from state sales tax and other levies as extended by the respective State Government.

In addition to that there are certain major incentives and facilities available to SEZ developers, right from, exemption from customs and excise duties for development of SEZs for authorized operations approved by the BOA, Income tax exemption on the income derived from the business of development of the SEZ in a block of 10 years in 15 years under section 80-IAB of the Income Tax Act, exemption from minimum alternate tax under 115JB of the Income Tax Act, exemption from dividend distribution tax under Section 1150 of the Income Tax Act, exemption from Central Sales Tax (CST) up to exemption from Service Tax (Section 7, 26 and Second schedule of SEZ Act) etc. (GOI, 2011)

\section{Review of Literature}

1. "Quality practices are investment in competitive resources and capabilities which bring competitiveness to the firm, by enhancing reliability, in the eye of customers through superior firm performance" Krajewski and Ritzman (1996), Khalil (2000)

2. "Management capacity as an investment in resources and capabilities makes progress towards competitiveness of a firm". Priyanto (2006), Verma (2002)

3. "The production capacity and utilisation is an investment in competitive resources that provide competitiveness to the firm by superior performance." Bavani (2006)

4. "Firms benefit from local production externalities, which exist when a firm's production possibilities depend on the actions of other firms located in the same region." Hanson (2001), Henderson (2003), and Agarwal (2004).

5. "Vision is one of the abilities of the entrepreneur to steer the firm ahead in the competitions" Vasant Desai (2006) 
6. "Providing hassle free environment to run business is one of the objectives of SEZ exim policy." Madani (1999) and Exim policy (2002-2007), SEZ Act, Ministry of Commerce, India

7. "Ability to procure goods from outside is one of the principal benefits of creating export" Agarwal (2004) and Ministry of India.

8. "Special Economic Zones in India - An Introduction" ASIEN, 106, January 2008 Jona Aravind Dohrmann,

9. Location strategy for competitiveness of Special Economic Zones in India - A Generic Framework, by Tarun Dhingra, Dr. Ambalika Sinha, and Dr. Tripti Singh ${ }^{3}$

\section{INDIAN EXPERIENCE IN IMPLEMENTATION OF SEZ}

Different states have different SEZ stories to tell. While some have done exceedingly well, others seem to be going nowhere.

i. Does the history of industrial development in the state determine, to any extent, the success of SEZs in that state?

ii. As each state coming up with its own SEZ policy

iii. Need to rank these states on an index based continuum that is constructed based on certain key parameters that could be used to evaluate the performance of SEZs.

Due to wide range of incentives, facilities and many other relaxations amended in SEZs, majority of the states in the country are motivated to set up SEZs to enjoy the advantages generated through these zones. Presently, there were 588 formal approvals of SEZ across 22 states in the country. 3 Out of this 386 SEZs are Notified. Among Various states Andhra Pradesh ranks first in the country with 4700 hectares of area under SEZs. The Other States like Tamilnadu, Maharashta and Gujarat are likely to have significant area under SEZ.

Table 1 Statewise distribution of SEZ Approvals

\begin{tabular}{|l|r|r|r|}
\hline State or Union Territory & Formal approvals & In Principle approval & Notified SEZ \\
\hline Andra Pradesh & 109 & 6 & 76 \\
\hline Chandigarh & 2 & 0 & 2 \\
\hline Chattisgarh & 1 & 1 & 1 \\
\hline Delhi & 3 & 0 & 0 \\
\hline Dadra \& Nagar Haveli & 2 & 0 & 1 \\
\hline Goa & 7 & 0 & 3 \\
\hline Gujarat & 47 & 7 & 32 \\
\hline Hariyana & 46 & 3 & 35 \\
\hline Jharkhand & 1 & 0 & 1 \\
\hline Karnataka & 62 & 1 & 41 \\
\hline Kerala & 29 & 0 & 20 \\
\hline Madhya Pradesh & 19 & 2 & 6 \\
\hline Maharshta & 103 & 16 & 64 \\
\hline Nagaland & 2 & 0 & 1 \\
\hline Orrisa & 10 & 1 & 5 \\
\hline Pondicherry & 1 & 1 & 0 \\
\hline Punjab & 8 & 0 & 2 \\
\hline Rajasthan & 10 & 1 & 10 \\
\hline Tamilnadu & 69 & 6 & 53 \\
\hline Uttar Pradesh & 34 & 1 & 21 \\
\hline Uttarkhand & 2 & 0 & 1 \\
\hline West Bengal & 20 & 3 & 11 \\
\hline Grand Total & 588 & 49 & 386 \\
\hline
\end{tabular}

Source: Ministry of Commerce and Industry, SEZ in India, GOI

It is to be noted that Out of total 588 approvals the selected states such as Andra Pradesh, Tamilnadu, Gujarat, Uttar Pradesh, West Bengal, Kerala, Karnataka, Madya Pradesh, Hariyana and Maharastra have contributed 499 approvals and the rest of the states contributed for remaining 89 approvals. It is unfortunate that some of the states have not shown any interest in SEZ. The following table shows state wise distribution of SEZ approvals. 
Figure : 1 Statewise distribution of SEZ Approvals

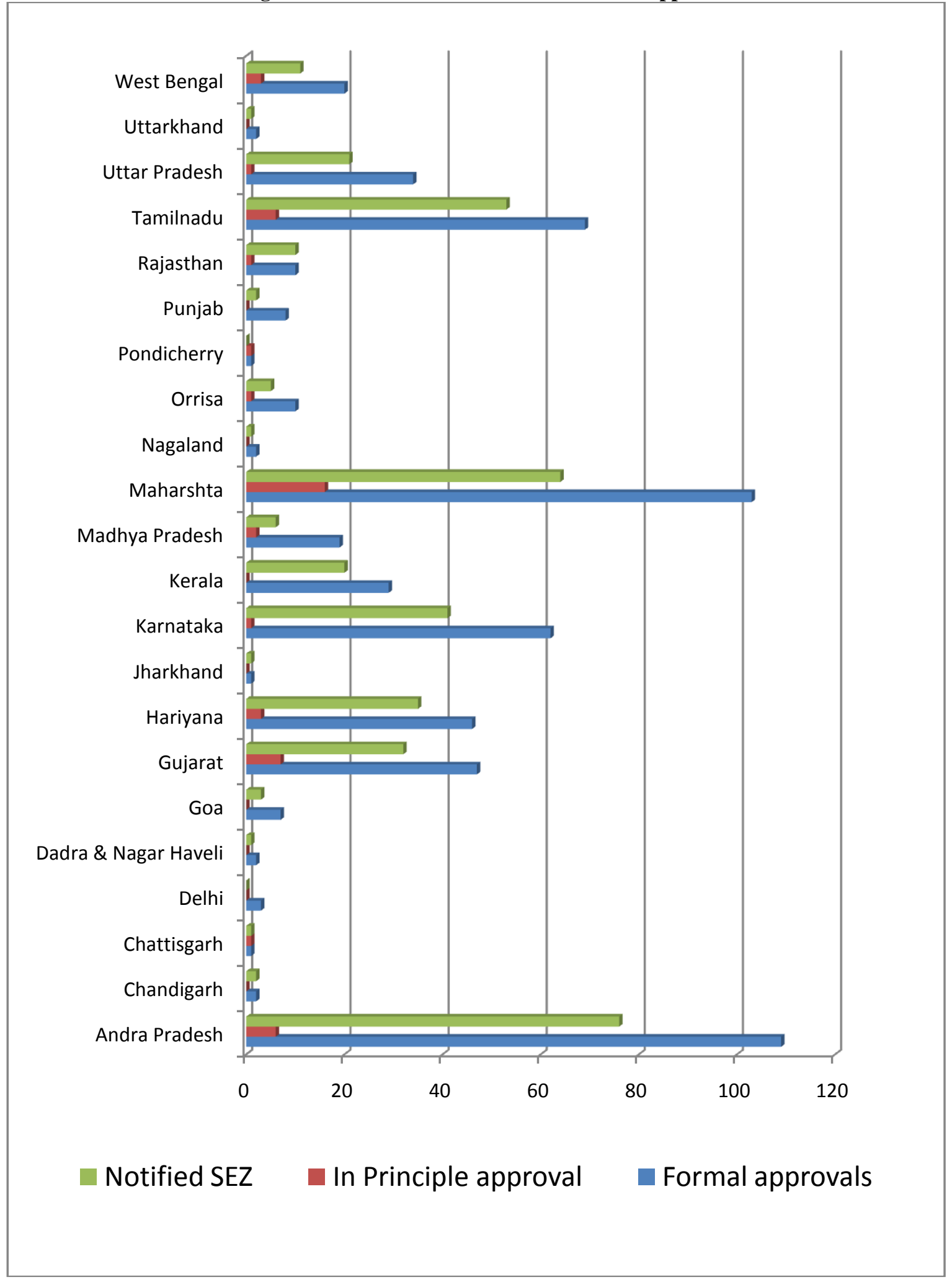

Those 588 formal approvals of SEZs, distributed among 28 industrial sectors in the country. Out of this 386 SEZs are Notified. Among several industries IT/ITES ranks first in the country, nearly 55\% of the total formal approvals and other industries like Biotech, petro chemical, Textiles, FTWZ and Gems \& Jewellary 4 likely to have significant share under SEZ. 
Table: 2 Sector wise distribution of SEZ Approvals

\begin{tabular}{|c|c|c|c|}
\hline Sectors & Formal approvals & In Principle approval & Notified SEZ \\
\hline Agro & 6 & 2 & 5 \\
\hline Airport based multiproduct & 4 & 0 & 0 \\
\hline Auto and related & 3 & 1 & 1 \\
\hline Aviation/aerospace/Copper & 2 & 1 & 1 \\
\hline Beach \& minerals/metals & 2 & 0 & 2 \\
\hline Biotech & 32 & 0 & 21 \\
\hline Building Product/materials & 1 & 2 & 1 \\
\hline Electronic Product/ind & 3 & 0 & 3 \\
\hline Food Processing & 5 & 0 & 4 \\
\hline Footwear / Leather & 7 & 0 & 5 \\
\hline FTWZ & 14 & 5 & 7 \\
\hline Gems and Jewellary & 13 & 3 & 6 \\
\hline Granite Processing Industry & 2 & 0 & 1 \\
\hline Handicraft & 5 & 0 & 3 \\
\hline $\begin{array}{l}\text { IT/ITES/Electronic Hardware/Semi } \\
\text { conductor }\end{array}$ & 353 & 1 & 235 \\
\hline Metal/St.Steel/Alum/Foundry & 9 & 2 & 5 \\
\hline Metallurgical Engineering & 1 & 0 & 0 \\
\hline Multiproduct & 25 & 16 & 16 \\
\hline Multi services/Services & 16 & 3 & 9 \\
\hline Non conventional energy & 6 & 0 & 4 \\
\hline Petro chemical \& petro & 4 & 1 & 2 \\
\hline Pharma/Chemical & 23 & 3 & 20 \\
\hline Plastic Processing & 0 & 2 & 0 \\
\hline Port based multiproduct & 8 & 0 & 2 \\
\hline Power/alternate energy/solar & 3 & 2 & 3 \\
\hline Strategic Manufacturing & 0 & 1 & 0 \\
\hline Textiles/Apparel/Wool & 18 & 2 & 12 \\
\hline Writing \& Printing paper mills & 2 & 0 & 1 \\
\hline GRAND TOTAL & 588 & 49 & 386 \\
\hline
\end{tabular}

Source: Ministry of Commerce and Industry, SEZ in India, GOI

Note: IT/ITES/ Electronic Hardware/Semiconductor will not be displayed in the following figure for effective comparison of other Sectors 
Figure :2 Sector wise distribution of SEZ approvals

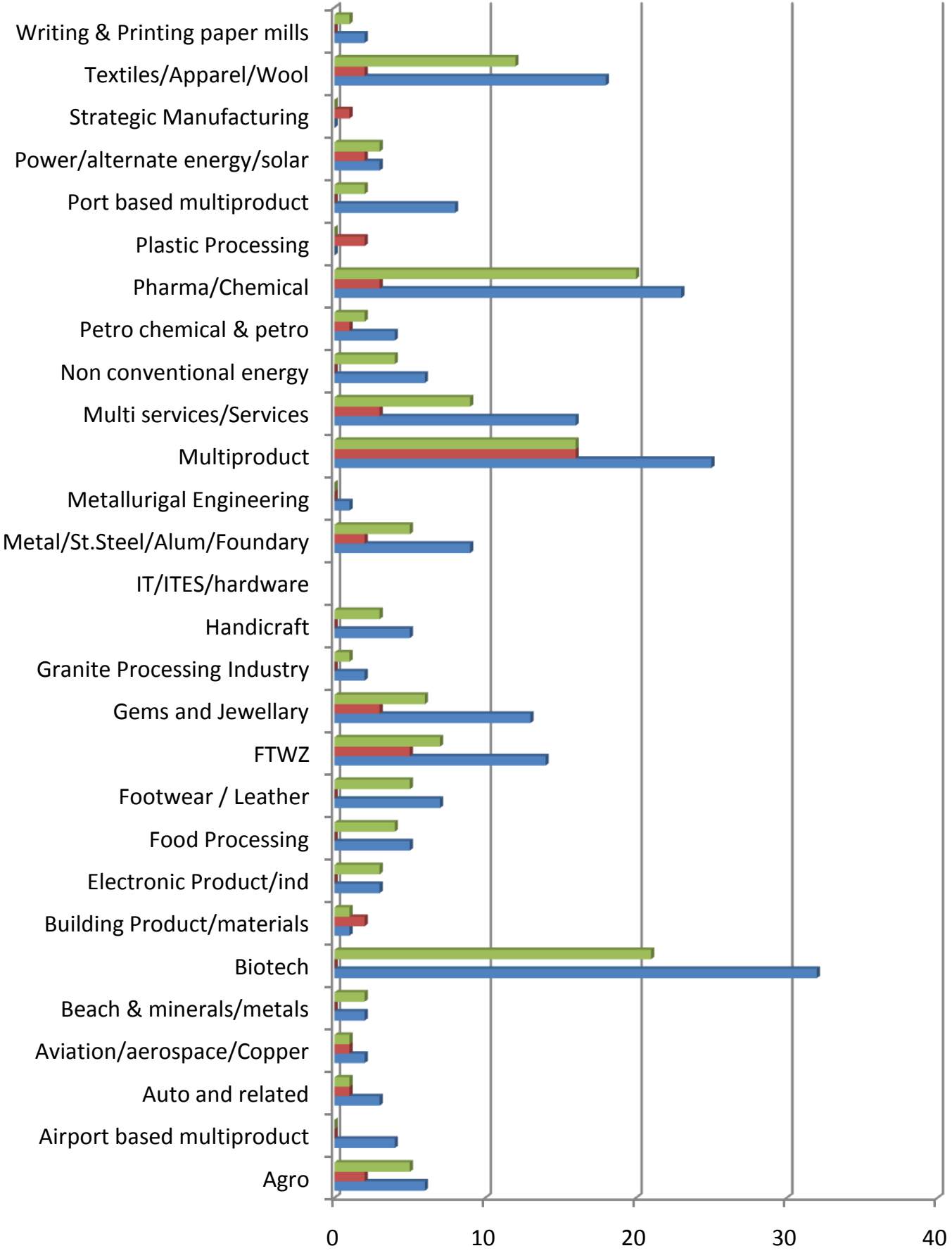

\section{Notified SEZ $\quad$ In Principle approval $\quad$ Formal approvals}

Based on the previous records, the SEZs in India have attracted significant private investment, apart from generating additional employment opportunities. As on November 30, 2007, there were 7 Central Government SEZs with a private investment of Rs.4,638.98 crores and 12 private/State Government new generation SEZs set up/notified prior to SEZ Act 2005 had an investment of Rs.52,354 crores.

Thus, the total private investment in SEZs worked out at Rs.59,630.98 crores. The total employment was estimated at 1,81,494 persons in the 7 Central Government SEZs, 59,356 persons in SEZs notified under the 
SEZ Act 2005, and 35,477 persons in 12 private/State Government new generation SEZs setup/notified prior to SEZ Act 2005 with a sum of 2,76,307 persons employed in all the SEZs put together (Table 1). The expected investment in new generation SEZs is estimated at Rs.1,00,000 crores including FDI of US \$ 5-6 billion by March 2008 and Rs.2,85,279 crores by December 2009. As for employment in new generation SEZs, as much as 1,00,000 direct jobs and 23,30,277 additional jobs are expected to be created by March 2008 and December, 2009, respectively. There are as many as 1122 approved units in 7 Central Government SEZs and 403 units in 12 Private/ State Government new generation SEZs setup/notified prior to SEZ Act 2005. 5

Table 3: Status of Employment and Investment in SEZs of India (As of November, 2007) Particulars

(a) Employment (in persons):

(i) In the 7 Central Government SEZs

(ii) SEZs notified under the SEZ Act 2005

$1,81,494$

(iii) 12 private/ State Government new generation SEZs notified prior to SEZ Act 2005

Total

(b) Current Investment (in Crore Rs.)

(i) In the 7 Central Government SEZs (Pvt. Investment only)

$4,638.98$

(ii) 12 private/ State Government new generation SEZs notified prior to SEZ Act 2005

(iii) SEZs notified under the SEZ Act 2005 Total

$52,354.00$

$59,630.98$

(c) Expected Investment and Employment

(i) Expected employment in new generation SEZs

By March 2008

By December 2009

$1,00,000$

$2,30,277$

direct jobs

(ii) Expected investment in new generation SEZs

By March 2008

Rs. $1,00,000 \quad$ crores

By December 2009

Including FDI of US \$ 5-6 billion

Rs. $2,85,279 \quad$ crores

Source: http://sezindia.nic.in

\section{Conclusion}

The Special Economic Zones (SEZs) notified under the SEZ Act 2005 have emerged as the major source of exports from the country. As on $21^{\text {st }}$ February 2012, there are 154 SEZs which have commenced exports. During the first nine months of current year (April-December 2011) the export from the SEZs have been to the tune of 2.60 lakh crores against export of 3.15 lakh crores during the complete year of 2010-11. Since the coming force of the SEZ Act in February 2006, the Zones have realized a total investment of 2.31 lakh crores. SEZ in India provide direct employment to over 8.15 lakh persons. The incremental employment generated by the SEZs in the short span of time since the Act came into force is of the order 6.80lakh persons. SEZs have made significant progress in terms of export, employment and investment.5

\section{End Notes}

1. Special Economic Zone (SEZ) is defined as "a specifically delineated duty free enclave and shall be deemed to be foreign territory for the purposes of trade operations and duties and tariffs". SEZs are an acknowledgement of the potential of export-led development strategy in accelerating economic growth.

2. Taken from the introduction to Special Economic Zones in India: http://www.sezindia.nic.in/ HTMLS/about.htm (last viewed on 12th July 2007).

3. As on October13, 2011, there were 588 formal approvals of SEZs in the country. Out of this, 386 SEZs were notified. The number of valid In-Principle approvals was 49

4. The new law allows the SEZs to have area of the order of 1000 hectares for multi-product zones, 100 hectares for product specific zones and only 10 hectares for IT, gems and jewellery and biotechnology zones.

5. Annual report 2011-12, Ministry of Commerce and Industry, GOI 


\section{References}

[1] Aggarwal Aradhana (2004). Export Processing Zones in India: Analysis of the Export Performance. - Working Paper No. 148. New Delhi: ICRIER

[2] Aggarwal, Aradhna (2006), 'Special Economic Zones:Revisiting the Policy Debate', Economic and Political Weekly, November 4, pp. 4533-4536.

[3] Arora, O P (2003). Compilation of Circulars on EPZ/SEZ/EOU issued by CBEC, DGFT \& RBI. Published byM/s Anmkur Arora Associates.

[4] Bhandari, Anup Kumar and Pradip Maiti (2007). Efficiency of Indian Manufacturing Firms: Textile Industry as a Case Study. International Journal of Business and Economics, 6 (1): 71-88.

[5] Bhavani T (1991). Technical Efficiency of Indian Small Scale Sectors: An Application of Frontier Production Function. Indian Economic Review. 26 (2): 149-166

[6] Goldar, B, V S Ranganathan and R Banga (2003). Ownership and Efficiency in Engineering Firms in Indian, 1990-91 to 1999-2000. ICRIER working Paper No. 115.

[7] Grasset, Jeremy and Frederic Landy (2007). Special Economic Zones in India-Between International Integration and Real Estate Speculation. Man and Development, 29 (4): 63-74.

[8] IIFT (1990). Exports Processing Zones in India: A Case Study of Kandla Free Trade Zone. Indian Institute of Foreign Trade Occasional Paper. New Delhi.

[9] Kambhampati Uma S (2003). Trade Reforms and Efficiency of Firms in India. Oxford Development Studies, 31(2): 219-33.

[10] Kumar, Ranjan (2006), 'SEZ: Capturing me Foreign Market',Southern Economist, September, Vol. 45.

[11] Tantri, Malini L (2010): "Effe ctiveness of SEZs over EPZs Structure: The Performance at Aggregate Level", ISEC Working Paper 248, Institute for Social and Economic Change (ISEC), Bangalore

[12] Trivedi Pushpa (2004): “An Inter State perspective on Manufacturing Productivity in India: 1980-81 to 2000-01", Indian Economic Review, 39(1): 203-237

[13] www.sez.nic.in

\section{Appendix $1 \quad$ Export Performances}

Exports from the functioning SEZs during 2003-04 to 2009-10

Year

2003-2004

2004-2005

2005-2006

2006-2007

2007-2008

2008-2009

2009-2010

\section{Value (Rs. Crore)}

13,854

18,314

22840

34,615

66,638

99,689

$2,20,711.39$
Growth Rate ( over previous year)

$39 \%$

$32 \%$

$25 \%$

$52 \%$

$93 \%$

$50 \%$

$121.40 \%$

Appendix 2

Statistics on SEZ

\begin{tabular}{|l|l|l|}
\hline \multirow{2}{*}{ Land for SEZs } & Notified SEZs & $\begin{array}{l}\text { Formally Approved including } \\
\text { notified }\end{array}$ \\
\cline { 2 - 3 } & $\mathbf{4 7 , 1 9 0}$ Hectare & $\mathbf{7 1 , 5 0 2}$ Hectare \\
\cline { 2 - 3 } & $\begin{array}{l}\text { Land is a state subject. Land for SEZs is procured as per the policy and } \\
\text { procedures of the respective State Government. }\end{array}$ \\
\hline Investment (as on 31/03/2012) & \multicolumn{1}{|c|}{ Incremental Investment } & \multicolumn{1}{|c|}{ Total Investment } \\
\hline SEZs Notified under the Act & US\$ 32.79 billion & US\$ 32.79 billion \\
\hline State/Pvt. SEZs before 2006 & US\$ 1.06 billion & US\$ 1.37 billion \\
\hline Central Government SEZs & US\$ 1.65 billion & US\$ 2.06 billion \\
\hline Total & US\$ 35.54 billion & US\$ 36.27 billion \\
\hline Employment(as on 31/03/ 2012) & Incremental Employment & Total Employment \\
\hline SEZs Notified under the Act & $5,52,048$ persons & $5,52,048$ persons \\
\hline State/Pvt. SEZs before 2006 & 66,547 persons & $\mathbf{7 9 , 0 1 5}$ persons \\
\hline Central Government SEZs & 91,617 persons & $2,13,853$ persons \\
\hline Total & $\mathbf{7 , 1 0 , 2 1 2}$ persons & $\mathbf{8 , 4 4 , 9 1 6}$ persons \\
\hline
\end{tabular}

Source: Special Economic Zones in India,Ministry of Commerce \& Industry,Department of Commerce 